Transactions of the American Fisheries Society, 2006, v.135, iss.1, p.12-27.

http://afs.allenpress.com/perlserv/?request=get-archive

http://afs.allenpress.com/archive/1548-8659/135/1/pdf/1548-8659-135-1-12.pdf

DOI: $10.1577 / \mathrm{T} 05-029.1$

ISSN: $1548-8659$

(C) Copyright by the American Fisheries Society 2006

\title{
Seasonal Consumptive Demand and Prey Use by Stocked Saugeyes in Ohio Reservoirs
}

Jonathan C. Sieber Denlinger and R. Scott Hale

Ohio Department of Natural Resources, Division of Wildlife

Roy A. Stein

Aquatic Ecology Laboratory, Department of Evolution, Ecology, and Organismal Biology, The Ohio State University.

\begin{abstract}
Community structure and species composition may be strongly influenced by predator-prey interactions resulting from and leading to episodes of population abundance or scarcity. We quantified diets of stocked saugeyes (female walleye Sander vitreus $\times$ male sauger $S$. canadensis) and estimated biomass of their primary prey, gizzard shad Dorosoma cepedianum, in three Ohio reservoirs at quarterly intervals during July 2002-July 2003 to determine whether saugeye consumptive demand could exceed the supply of available gizzard shad prey, resulting in a shift to alternative prey. We incorporated water temperature and saugeye diet composition, growth, and mortality into walleye bioenergetics models, which allowed us to compare estimated prey-specific consumption rates by saugeyes with gizzard shad standing stocks estimated with acoustics. Spring and summer were critical seasons. During spring, gizzard shad biomass was low, saugeye consumptive demand was low, and saugeyes consumed primarily alternative prey. During summer, when age-0 gizzard shad became available as prey, saugeyes consumed similar proportions of gizzard shad and alternative prey. Saugeye cumulative consumptive demand in summer was high and approached the gizzard shad standing stock. However, during fall and winter, gizzard shad supply was adequate to support high (fall) or declining (winter) saugeye consumptive demand. Across reservoirs and seasons, saugeyes consumed alternative prey to varying degrees, primarily sunfishes Lepomis spp., yellow perch Perca flavescens, logperch Percina caprodes, and minnows Pimephales spp. Seasonal asynchrony between saugeye consumptive demand and gizzard shad biomass during spring and summer indicated that a saugeye population with high survival, growth, and consumptive demand will opportunistically increase use of prey other than gizzard shad. The manner in which saugeye predation quantitatively influences these prey species could not be assessed. However, overexploitation of gizzard shad prey appears to be unlikely at current saugeye population sizes, particularly considering the opportunistic use of alternative prey and the high reproductive potential of gizzard shad.
\end{abstract}

Imbalance between predator consumptive demand and prey availability can lead to oscillations of population abundance or scarcity that structure aquatic communities. Sport fish stocking and recruitment can greatly influence reservoir ecosystems; therefore, matching predator stocking density with prey fish availability is an important challenge that has most successfully been achieved through the stocking of predators (Carlander 1958; Noble 1981; Stewart et al. 1981; DeVries and Stein 1990; Eggold and Horns 2001; Aprahamian et al. 2003) as opposed to prey manipulations.

The Ohio Division of Wildlife began stocking Ohio reservoirs with saugeyes (female walleye Sander vitreus $\times$ male sauger S. canadensis) in 1978 to supplement a declining walleye fishery and capitalize on abundant gizzard shad Dorosoma cepedianum in shallow, fertile reservoirs (Lynch et al. 1982; Silk 2001; Spoelstra 2001). Due to the faster growth and higher survival of saugeyes versus walleyes, these hybrids may offer managers a valuable stocking 
alternative to walleyes (Johnson et al. 1988a). Indeed, annual stocking of 6-10 million saugeye fingerlings has created a substantial sport fishery in Ohio reservoirs (Ohio Division of Wildlife, unpublished data).

Though stocked saugeyes consume a variety of prey, predominately shads Dorosoma spp., crappies Pomoxis spp., sunfishes Lepomis spp., silver-sides Menidia spp., and yellow perch Perca flavescens (Humphreys et al. 1987; Johnson et al. 1988a; Leeds 1992), gizzard shad (and their larvae) are particularly important to saugeye stocking success (Stahl and Stein 1994; Donovan et al. 1997). Gizzard shad thrive in the shallow (typical mean depth $=4-5 \mathrm{~m}$ ), mesotrophic-eutrophic (typical total $\mathrm{P}=20-60 \mu \mathrm{g} / \mathrm{L}$ ) reservoirs found throughout Ohio and are the epitome of dense, highly variable prey fish populations (Bremigan and Stein 2001). Interactions between gizzard shad and saugeyes clearly influence stocking success and the resulting reservoir food webs.

Ideally, if gizzard shad standing stocks exceed the consumptive demand of reservoir predators, then surplus prey exist for potential conversion to sport fish biomass. However, if consumptive demand by predators exceeds available prey resources, predators could be increasingly forced to consume alternative prey resources (e.g., sport fishes such as largemouth bass Micropterus salmoides, sunfishes, or crappies). Herein, we quantify the seasonal impact of stocked saugeyes on gizzard shad in three Ohio reservoirs and examine current saugeye stocking rates, available prey, and effect on recruitment of resident sport fishes. More specifically, we sought to (1) determine whether the availability of gizzard shad prey meets saugeye consumptive demand, (2) evaluate the potential influence saugeyes may have on resident sport fish populations, and (3) use bioenergetics simulations in which saugeye survival, diet, and growth are manipulated to explore the capacity of gizzard shad prey to sustain saugeye populations.

\section{Methods}

Study reservoirs and sampling regime. - Our efforts focused on three Ohio reservoirs that represented a range of productivities and therefore a range of gizzard shad densities (Bremigan and Stein 2001). These three reservoirs, in order of increasing productivity, were mesotrophic Burr Oak Reservoir $(\mathrm{TP}=43.0 \mu \mathrm{g} / \mathrm{L})$, somewhat more productive Piedmont Reservoir $(\mathrm{TP}=$ $49.8 \mu \mathrm{g} / \mathrm{L})$, and eutrophic Pleasant Hill Reservoir $(\mathrm{TP}=85.5 \mu \mathrm{g} / \mathrm{L})($ Knoll et al. 2003). Inshore littoral habitat $(<1.5 \mathrm{~m}$ deep) is similar in all reservoirs (19-23\%). Acoustic surveys conducted in 2001 by the Ohio Department of Natural Resources (R.S.H., unpublished data) revealed that mean $( \pm \mathrm{SE})$ gizzard shad densities in these reservoirs were $0.07 \pm 0.01 \mathrm{fish} / \mathrm{m}^{2}$ in Burr Oak Reservoir, $1.19 \pm 0.15 \mathrm{fish} / \mathrm{m}^{2}$ in Piedmont Reservoir, and $1.97 \pm 0.26 \mathrm{fish} / \mathrm{m}^{2}$ in Pleasant Hill Reservoir. Saugeyes stocked annually in Burr Oak, Piedmont, and Pleasant Hill reservoirs were reared at the Hebron, St. Mary's, or Senecaville state fish hatcheries in Ohio. Managers typically stock saugeyes in mid-May through early June as 25-45-mm (total length [TL]) fingerlings.

Looking broadly across the year, we hypothesized that particular seasons could be differentially important for understanding saugeye-prey dynamics, namely, (1) early spring, before gizzard shad spawn; (2) early summer, when prey consumption by saugeyes is likely to be high; (3) fall, when water temperatures are declining and these cool-water predators may be at a physiological advantage when preying on warmwater prey; and (4) winter, when a reduction in reservoir water level may intensify predator-prey interactions. Thus, we sampled all three reservoirs during July (early summer) and November (fall) 2002 and March (late winter), May (spring), and July 2003 (July samples provided year-to-year comparisons). Each sample period consisted of saugeye, gizzard shad, and water quality sampling. 
Saugeye sampling. - Saugeyes were collected with electrofishing gear and experimental gill nets. Night electrofishing consisted of twelve 20-min shoreline transects, all within $5 \mathrm{~m}$ of the shore. Boats were equipped with Smith-Root model 5.0 GPP electrofishers set as follows: DC mode; low 50-500-V range; 60 pulses/s; and 2-5-A output. Due to the size selectivity associated with electrofishing, we also sampled saugeyes with experimental gill nets. Experimental gill nets were $30.5 \mathrm{~m}$ long, $1.8 \mathrm{~m}$ high, and consisted of five $6.1-\mathrm{m}$ panels with mesh sizes of 1.9, 2.5, 3.8, 5.1, and $6.4 \mathrm{~cm}$. Gill nets were deployed perpendicular to the shore at 1.8-7.6-m depths, were set $1 \mathrm{~h}$ before sunset, and were fished for about $2 \mathrm{~h}$. Saugeyes were stored on wet ice and processed in the laboratory.

Saugeyes captured by electrofishing during July 2002-2003 were measured (nearest $\mathrm{mm}$ ) and weighed (nearest g). Stomachs were pumped from a subsample of fish (Foster 1977), and diet contents were recovered and stored in 95\% ethyl alcohol; alternatively, fish were stored on ice for similar data collection. All saugeyes were then released except for those we sacrificed for collection of otoliths for aging (about 35 fish/sample night). From sacrificed fish, we also removed and quantified stomach contents in the laboratory to estimate the efficiency of gastric lavage (96\% were empty, $N=103$ fish) and to recover additional prey that were not removed during stomach pumping. For saugeyes that were returned to the reservoir, only lengths were measured.

Vertebrate prey in diets were identified to the lowest possible taxon, and prey TL was measured. We measured the maximum length of partial vertebra segments and did not extrapolate from these measures to fish TL. We estimated TL of partially digested gizzard shad based on the intact gizzard when present (Bryant and Morais 1970). Invertebrates were identified to order and desiccated at $60^{\circ} \mathrm{C}$, and their caloric densities were estimated (Cummins and Wuycheck 1971).

Saugeye age was determined by counting annuli from otoliths submerged in glycerol and viewed under a 7-30× dissecting microscope. For age- 2 and older saugeyes with whole otoliths, we subsequently cracked their otoliths at the focus and polished them with wetted 600-grit sandpaper. Otoliths then were mounted in black modeling clay and submerged in water, and annular rings were read with the aid of a fiber optic light source (Secor et al. 1991).

Gizzard shad abundance, size, and biomass estimation. - We conducted five mobile acoustic surveys in each reservoir to coincide with our saugeye sampling. By use of methodology similar to stock assessments of rainbow smelt Osmerus mordax in Lake Oahe, South Dakota (Burczynski et al. 1987), our acoustic surveys characterized gizzard shad abundance, mean size, and biomass in each reservoir. Recommended survey design and settings were as provided by Don Degan (Aquacoustics, Inc., personal communication). We used a BioSonics DT6000 echosounder with two $6^{\circ}$ circular, 200-kHz split-beam transducers (2002) or a BioSonics DE6000 echosounder with one $4 \times 8^{\circ}$ elliptical, 200-kHz split-beam transducer (vertical) and one $6^{\circ}$ circular, 200-kHz split-beam transducer (horizontal) (2003). For all samples, one transducer was mounted for horizontal surveys and the other was mounted for vertical surveys. Equipment was calibrated to U.S. Navy standards by BioSonics, Inc., Seattle, Washington, prior to each use; field calibration was performed before each survey by use of a tungsten carbide reference sphere following the procedures recommended by Foote and MacLennan (1984). The vertical transducer was deployed $0.5 \mathrm{~m}$ below the surface, and the horizontal transducer was deployed $1 \mathrm{~m}$ below the surface. We set echo integration processing parameters to process data within $0.25 \mathrm{~m}$ of the bottom for the vertical data and from 1 to $20 \mathrm{~m}$ from the transducer for the horizontal data. 
Surveys began $30 \mathrm{~min}$ after sunset at speeds of $8-9 \mathrm{~km} / \mathrm{h}$. We navigated fixed cruise tracks with global positioning system waypoints across the limnetic region of each reservoir. Based on reservoir morphology, we used a parallel track, a zigzag track, or combination of parallel and zig-zag tracks. In each reservoir, randomly selected 250-m transect segments were used to estimate abundance and biomass $(N=20$ in Burr Oak and Pleasant Hill reservoirs; $N=$ 36 in Piedmont Reservoir). Fish were sampled at 4 pings/s, a - 60-decibal (dB) threshold, a pulse width of $0.2 \mathrm{~ms}$, a start range of $1 \mathrm{~m}$, and a stop range that varied from 10 to $20 \mathrm{~m}$ depending upon the reservoir sampled and the transducer position (vertical or horizontal).

Areal estimates of density and biomass were derived by echo integration (MacLennan and Simmonds 1992). Data analysis was performed by Don Degan (Aquacoustics, Inc.) in Echoview 3.0 or 3.1 software (SonarData, Inc.). Each vertical data file was processed with 1-m vertical strata from $1.5 \mathrm{~m}$ below surface to near the bottom; bottom signals were removed by manual editing in Echoview. Horizontal file analysis was similar to vertical file analysis except that a single range stratum was offered. Data were processed to obtain the mean acoustic size of fish for scaling echo integration to estimate densities. Total reflected voltages from echo integration were converted to absolute areal densities by scaling the voltages by the average backscattered cross section from individual fish targets within $4 \mathrm{~dB}$ of the center of the transducer beam. Acoustic size data were transformed to fish lengths by means of Love's dorsal aspect equation (Love 1971). Estimates of gizzard shad lengths were applied to a length-weight equation for gizzard shad in Ohio reservoirs $\left(\log _{e}[\right.$ weight $]=2.7875 \cdot \log _{e}[$ length $\left.]-10.5461\right)$ to derive mean weight and population biomass.

Consumptive demand, thermal environment, and prey consumption.- Saugeye consumptive demand was determined through bioenergetics modeling. We based our model on the mass balance equation described by Kitchell et al. (1977) for walleyes:

$$
G=C-(M+F+U)
$$

such that $G=$ growth rate, $C=$ consumption rate, $M=$ metabolic rate (including standard metabolism, active metabolism, and specific dynamic action), $F=$ egestion rate, and $U=$ excretion rate. Using software developed by Hanson et al. (1997), we incorporated a variety of measured and referenced variables to determine daily energetic values necessary for saugeye survival and growth. Similar to other bioenergetics studies that have "borrowed" physiological parameters of parental species for hybrid offspring simulations (Dettmers et al. 1998; Whitledge et al. 1998), we used the adult walleye model (Kitchell et al. 1977; Hanson et al. 1997) for age-1 and older saugeyes and the juvenile walleye model (Madon and Culver 1993) for saugeyes younger than age 1.

Study-specific parameters, as integrated in the model, consisted of measured growth rates, thermal experience, diet composition, and estimated abundance. Seasonal saugeye growth rates and diet for each cohort were quantified during each sample period. The model interpolated growth and diet composition values between sample dates. We estimated saugeye thermal experience for each reservoir based on measured vertical temperature and oxygen profiles at upstream and downstream sites, indicating suitable habitat during each season. Thermal structure was measured during July 2002 through July 2003 with remote thermistors and was incorporated into the model on a daily basis (coolest water with oxygen $>4 \mathrm{mg} / \mathrm{L}$ ); values were therefore not interpolated. We estimated the saugeye population size in each reservoir from historical stocking densities and adult catch curves based on data collected during November 2002 electrofishing. 
Age-0 saugeye mortality from the stocking date to fall was estimated from the relationship between fall catch per unit effort (CPUE; fish/h) of age-0 saugeyes and known stocking densities (fish/acre): age-0 survival to fall $=0.1158 \times[\mathrm{CPUE} /($ stocking density) $]+0.0174$ (D. Walters, Ohio Division of Wildlife, Xenia, Ohio, unpublished data; E. M. Marschall, The Ohio State University, Aquatic Ecology Laboratory, Columbus, Ohio, unpublished data). The population of age-0 saugeyes in July was estimated by fitting a logarithmic curve between the known number of fish stocked (spring) and the estimated population in fall. To estimate the daily population size of each cohort, we subjected the known saugeye stocking rates to daily mortality rates by use of estimated first-summer mortality for age- 0 fish and annual mortality rates for adult fish $(\geq 1$ year). By inputting growth rates, estimated population size, predator and prey caloric values determined from the literature, and water temperature, we back-calculated food consumption by saugeyes. The proportion $(P)$ of maximum consumption $\left(C_{\max }\right)$ was estimated based on growth rates and thermal experience. Food consumption was partitioned into different prey compartments by determining proportional representation of different prey in saugeye diets on a seasonal basis. Laboratory-measured prey lengths $(\mathrm{mm})$ were converted to estimated prey mass (g) based on length-weight equations for each prey taxon and available caloric values from the literature (Table 1).

Corresponding to the same time periods used to generate gizzard shad densities, cumulative consumption of prey by each saugeye cohort $(\leq 1999-2003)$ during July 2002-July 2003 was estimated. We then determined cumulative consumption by the entire saugeye population within the following simulation periods: July 2002 (15 July-28 August), November 2002 (29 August-29 December), March 2003 (30 December 2002-31 March 2003), May 2003 (1 April-6 June), and July 2003 (6 June-20 July). Irwin et al. (2003b) used a similar approach to examine largemouth bass predatory demand and its ability to control gizzard shad in small impoundments.

In addition to our reservoir-specific estimates of consumption by saugeyes (hereafter

"best estimate") and to judge the predatory potential of saugeyes, we varied our measured and calculated variables (oversummer age-0 saugeye survival, annual adult saugeye survival [S], proportion of gizzard shad in saugeye diets [D], and seasonal saugeye growth [G]) to model general scenarios leading to levels of low, intermediate, and high (hereafter, LSDG, ISDG, and HSDG, respectively) saugeye standing stocks and corresponding levels of consumptive demand (Table 2). Values for oversummer age-0 saugeye survival reflected the range historically documented in Ohio reservoirs during 1993 and 1994 (Donovan et al. 1997). The range of annual adult survival was derived from saugeye catch curves in Burr Oak, Piedmont, and Pleasant Hill reservoirs during November 2002. Ranges of the gizzard shad proportion in diets and seasonal saugeye growth were derived from Burr Oak, Piedmont, and Pleasant Hill reservoirs during July 2002-July 2003. The saugeye stocking rate (247 fish/ha) used in each scenario was the mean rate of stocking by the Ohio Division of Wildlife in 57 water bodies throughout Ohio during 2003 and was lower than the stocking rates at Burr Oak, Piedmont, and Pleasant Hill reservoirs during 2003 (254, 454, and 538 fish/ha, respectively). Saugeye thermal experience, based on fieldmeasured values, was the mean of temperature regimes in Burr Oak, Piedmont, and Pleasant Hill reservoirs during July 2002-July 2003.

\section{Results}

Saugeye Growth

Mean individual mass of age-0 saugeyes was generally highest in Burr Oak Reservoir, 
lower in Piedmont Reservoir, and lowest in Pleasant Hill Reservoir (Table 3). Most commonly, the mean mass of adult (age $\geq 1$ ) saugeyes within cohorts was highest in Pleasant Hill Reservoir, lower in Burr Oak Reservoir, and lowest in Piedmont Reservoir; however, this trend between reservoirs was not always significant (Table 3). Saugeye sample size in Burr Oak Reservoir was small during all seasons.

Table 1. - Length-weight $(L-W)$ equations and caloric values of saugeye prey items from available literature, as included in bioenergetics model

\begin{tabular}{|c|c|c|c|c|}
\hline Species & $L-W$ equation & $\begin{array}{l}L-W \text { equation } \\
\text { source }\end{array}$ & $\begin{array}{c}\text { Caloric } \\
\text { value }(\mathrm{J} / \mathrm{g})\end{array}$ & $\begin{array}{l}\text { Caloric value } \\
\text { source }\end{array}$ \\
\hline Gizzard shad & $\log _{e} W=2.7875 \log _{e} L-10.5461$ & $\begin{array}{l}\text { Hale et al. } \\
\text { (unpub- } \\
\text { lished) }\end{array}$ & 5,103 & $\begin{array}{l}\text { Miranda and } \\
\text { Muncy } \\
\text { (1991) }\end{array}$ \\
\hline Sunfishes & $\log _{e} W=-12.08+3.29 \log _{e} \mathrm{TL}$ & $\begin{array}{l}\text { Wahl and } \\
\text { Stein } \\
\text { (1991) }\end{array}$ & 4,852 & $\begin{array}{l}\text { Miranda and } \\
\text { Muncy } \\
\text { (1991) }\end{array}$ \\
\hline Crappies & $\log _{e} W=-11.67+3.00 \log _{e} \mathrm{TL}$ & $\begin{array}{l}\text { Wahl and } \\
\text { Stein } \\
\text { (1991) }\end{array}$ & 3,500 & $\begin{array}{l}\text { Bunnell } \\
\quad \text { (unpublished) }\end{array}$ \\
\hline Yellow perch & $\log _{e} W=2.8535 \log _{e} L-10.3875$ & $\begin{array}{l}\text { Henderson et } \\
\text { al. (2000) }\end{array}$ & 3,345 & $\begin{array}{l}\text { Madon and } \\
\text { Culver }(1993)\end{array}$ \\
\hline Brook silverside Labidesthes sicculus & $\log _{e} W=-11.78+2.91 \cdot \log _{e} \mathrm{TL}$ & $\begin{array}{l}\text { Wahl and } \\
\text { Stein } \\
(1991)\end{array}$ & 4,392 & $\begin{array}{l}\text { Pope et al. } \\
\quad(2001)\end{array}$ \\
\hline Minnows Pimephales spp. & $\log _{e} W=-13.96+3.55 \log _{e} \mathrm{TL}$ & $\begin{array}{l}\text { Wahl and } \\
\text { Stein } \\
\text { (1991) }\end{array}$ & 4,392 & $\begin{array}{l}\text { Bryan et al. } \\
\text { (1996) }\end{array}$ \\
\hline Logperch Percina caprodes & $\log _{e} W=2.8535 \log _{e} L-10.3875$ & $\begin{array}{l}\text { Henderson et } \\
\text { al. (2000) }\end{array}$ & $4,392^{\mathrm{a}}$ & $\begin{array}{l}\text { Bryan et al. } \\
\text { (1996) }\end{array}$ \\
\hline Largemouth bass & $\log _{e} W=2.96211 \log _{e} L-4.79809$ & $\begin{array}{l}\text { Kramer and } \\
\text { Smith } \\
(1960)\end{array}$ & 4,184 & $\begin{array}{l}\text { Rice et al. } \\
\text { (1983) }\end{array}$ \\
\hline Johnny darter Etheostoma nigrum & $\log _{e} W=\exp [-2.92+(3.06 \log L)] / 10$ & $\begin{array}{l}\text { Lotrich } \\
\text { (1973) }\end{array}$ & $3,345^{\mathrm{b}}$ & $\begin{array}{l}\text { Madon and } \\
\text { Culver (1993) }\end{array}$ \\
\hline White bass Morone chrysops & $\log _{e} W=-13.96+3.55 \log _{e} T L$ & $\begin{array}{c}\text { Wahl and } \\
\text { Stein } \\
(1991)\end{array}$ & $4,392^{\mathrm{a}}$ & $\begin{array}{l}\text { Bryan et al. } \\
\quad(1996)\end{array}$ \\
\hline Catfishes Ictalurus spp. & $W=3 \times 10^{6} \cdot L^{3.3072}$ & $\begin{array}{c}\text { Denlinger } \\
\text { (unpub- } \\
\text { lished) }\end{array}$ & 5,437 & $\begin{array}{l}\text { Masser et al. } \\
\quad(1991)\end{array}$ \\
\hline Other fishes & & & $4,391^{\mathrm{c}}$ & \\
\hline Invertebrates & & & $4,121^{\mathrm{d}}$ & $\begin{array}{l}\text { Cummins and } \\
\text { Wuycheck } \\
\text { (1971) }\end{array}$ \\
\hline
\end{tabular}

a Value of minnow (Bryan et al. 1996).

b Value of age-0 yellow perch (Madon and Culver 1993).

${ }^{c}$ Value derived from mean caloric value of johnny darter, white bass, and catfishes.

d Value derived from mean value of orders Diptera, Ephemeroptera, Hemiptera, Odonata, and other insects.

\section{Gizzard Shad Density and Biomass}

Across reservoirs, during July and November 2002 and May 2003, gizzard shad density was highest in Pleasant Hill Reservoir and lowest in Burr Oak and Piedmont reservoirs, which were equal (one-way analysis of variance [ANOVA]: $F_{2,75}=29.45$ in July, 22.04 in November, and 8.79 in May; all $P<0.005$; Table 4). Gizzard shad densities deviated from this pattern during March 2003, when densities in Pleasant Hill and Burr Oak reservoirs were not significantly different ( $t$-test: $P=0.31$ ), and both were significantly higher than that of Piedmont reservoir ( $t$-test: $P<0.004)$. Densities also deviated from the general pattern during July 2003, 
when densities in the three reservoirs did not differ significantly (one-way ANOVA: $F_{2,75}=1.93$, $P=0.15$; Table 4).

Table 2. - Bioenergetics model parameters used for simulations of low, intermediate, and high saugeye survival, proportion of gizzard shad in the diet, and growth (LSDG, ISDG, and HSDG). Each simulation included the mean saugeye stocking rate by the Ohio Division of Wildlife during 2003 (247 fish/ha); likewise, each simulation's temperature regime included the mean of field-measured temperature regimes from Burr Oak, Piedmont, and Pleasant Hill reservoirs (July 2002-July 2003).

\begin{tabular}{llcc}
\hline \multicolumn{1}{c}{ Model variable } & LSDG & ISDG & HSDG \\
\hline Oversummer age-0 sauge survival (\%) & 0.9 & 6.2 & 11.7 \\
Annual adult saugeye survival (\%) & 36.0 & 50.0 & 64.0 \\
Gizzard shad in saugeye diets (\%) & $16-42$ & $48-90$ & $75-93$ \\
Seasonal saugeye growth & Lowest observed & Intermediate observed & Highest observed \\
\hline${ }^{a}$ LSDG and HSDG numbers are based on measured oversummer age-0 saugeye survival in Ohio reservoirs (Donovan et al. 1997). \\
b LSDG and HSDG values are based on the range of calculated annual adult saugeye survival rates in Burr Oak, Piedmont, and Pleasant \\
Hill reservoirs during July 2002-July 2003; the ISDG value is the mean of the LSDG and HSDG values.
\end{tabular}

Seasonally, gizzard shad biomass (kg/ha) in Burr Oak Reservoir was highest in November 2002, and lower in July 2002, March 2003, and July 2003, which were not significantly different; gizzard shad biomass was lowest during March and May 2003, which also did not differ in biomass (one-way ANOVA: $P<0.0001$; Tukey's honestly significant difference [HSD] test: $\alpha=$ 0.05; Table 4). In Piedmont Reservoir, gizzard shad biomass was highest in November 2002 and July 2003 (these months were not significantly different) and lower in July 2002 and May 2003 (these months did not differ); gizzard shad biomass was lowest during March and May 2003 (one-way ANOVA: $P<0.0001$; Tukey's HSD: $\alpha=0.05$; Table 4). In Pleasant Hill Reservoir, gizzard shad biomass was greatest in November 2002 and lowest in July 2002 and March, May, and July 2003; these latter biomass values did not differ significantly (one-way ANOVA: $P<$ 0.0001; Tukey's HSD: $\alpha=0.05$; Table 4).

\section{Saugeye Prey}

Gizzard shad in saugeye diets varied seasonally within and across reservoirs, but diet proportion was typically over $75 \%$ gizzard shad by mass. Mean contribution of gizzard shad to saugeye diets across seasons and cohorts was highest in Burr Oak Reservoir, lower in Pleasant Hill Reservoir, and lowest in Piedmont Reservoir (Figure 1). Non-gizzard shad prey, consisting primarily of sunfishes, yellow perch, and logperch, were particularly important ( $>38 \%$ of diets, by mass) during July 2002 and 2003 in Pleasant Hill Reservoir. During March, May, and July 2003 in Piedmont Reservoir, non-gizzard shad prey (primarily sunfishes, yellow perch, crappies, minnows, and logperch) accounted for $63-99 \%$ of diet contents by mass. 
Table 3. - Seasonal mass (wet weight [g] with $95 \%$ confidence interval $[\mathrm{CI}]$ ) for each saugeye age-class at Burr Oak, Piedmont, and Pleasant Hill reservoirs, Ohio, sampled during July 2002-July 2003.

\begin{tabular}{|c|c|c|c|c|c|c|c|c|c|c|c|}
\hline \multirow{2}{*}{$\begin{array}{l}\text { Saugeye } \\
\text { cohort }\end{array}$} & \multirow{2}{*}{$\begin{array}{c}\text { Age } \\
\text { (years) }\end{array}$} & \multirow{2}{*}{$\begin{array}{c}\text { Sample } \\
\text { month and } \\
\text { year }\end{array}$} & \multicolumn{3}{|c|}{ Burr Oak } & \multicolumn{3}{|c|}{ Piedmont } & \multicolumn{3}{|c|}{ Pleasant Hill } \\
\hline & & & $N$ & Weight & $95 \% \mathrm{CI}$ & $N$ & Weight & $95 \% \mathrm{CI}$ & $N$ & Weight & $95 \% \mathrm{CI}$ \\
\hline 2003 & $<1$ & Jul 2003 & 9 & 17.9 & 3.5 & 9 & 21.7 & 6.2 & $47^{\mathrm{a}}$ & 7.2 & 4.2 \\
\hline \multirow[t]{5}{*}{2002} & $<1$ & Jul 2002 & 3 & 26.0 & 12.6 & 1 & 10.0 & & 47 & 7.2 & 1.2 \\
\hline & $<1$ & Nov 2002 & 7 & 116.6 & 28.2 & 40 & 105.1 & 10.3 & 267 & 78.2 & 7.9 \\
\hline & 1 & Mar 2003 & 4 & 138.0 & 37.2 & 37 & 124.1 & 11.3 & 86 & 111.5 & 13.8 \\
\hline & 1 & May 2003 & 2 & 143.0 & 37.2 & 38 & 104.0 & 10.5 & 308 & 76.0 & 4.9 \\
\hline & 1 & Jul 2003 & 2 & 207.0 & 2.0 & 32 & 178.8 & 13.7 & 111 & 82.7 & 8.3 \\
\hline \multirow[t]{5}{*}{2001} & 1 & Jul 2002 & 2 & 167.5 & 38.2 & 171 & 170.4 & 7.6 & 65 & 251.1 & 20.0 \\
\hline & 1 & Nov 2002 & 4 & 372.8 & 121.1 & 311 & 345.9 & 9.3 & 50 & 599.4 & 29.4 \\
\hline & 2 & $\operatorname{Mar} 2003$ & 5 & 385.4 & 68.5 & 170 & 384.8 & 12.0 & 46 & 671.5 & 33.5 \\
\hline & 2 & May 2003 & 1 & 666.0 & & 34 & 317.3 & 24.3 & 35 & 660.9 & 40.7 \\
\hline & 2 & Jul 2003 & 6 & 949.3 & 158.9 & 28 & 336.5 & 53.8 & 27 & 896.2 & 109.4 \\
\hline \multirow[t]{5}{*}{2000} & 2 & Jul 2002 & 3 & 485.7 & 229.6 & 8 & 507.1 & 71.8 & 17 & 598.8 & 53.8 \\
\hline & 2 & Nov 2002 & 7 & 713.9 & 120.3 & 7 & 600.7 & 55.2 & 49 & 998.6 & 57.9 \\
\hline & 3 & Mar 2003 & 9 & 898.6 & 140.9 & 8 & 651.6 & 107.9 & 33 & $1,172.0$ & 81.7 \\
\hline & 3 & May 2003 & 4 & 977.3 & 206.8 & 2 & 486.5 & 99.0 & 22 & $1,079.1$ & 86.5 \\
\hline & 3 & Jul 2003 & 2 & $1,309.5$ & 434.1 & 1 & 909.0 & & 2 & $1,564.0$ & 566.4 \\
\hline \multirow[t]{5}{*}{$\leq 1999$} & $\geq 3$ & Jul 2002 & 13 & $1,521.3$ & 351.8 & 6 & 788.8 & 229.1 & 3 & $2,182.7$ & 442.3 \\
\hline & $\geq 3$ & Nov 2002 & 11 & $1,982.5$ & 363.9 & 32 & $1,024.9$ & 120.2 & 11 & $2,095.4$ & 564.1 \\
\hline & $\geq 3$ & Mar 2003 & 16 & $2,137.4$ & 469.9 & 28 & $1,023.5$ & 139.8 & 5 & $2,347.6$ & 289.7 \\
\hline & $\geq 3$ & May 2003 & 5 & $1,900.0$ & 627.0 & 9 & 926.9 & 160.6 & 8 & $1,967.5$ & 537.4 \\
\hline & $\geq 3$ & Jul 2003 & 1 & $1,524.0$ & & 2 & 931.5 & 122.5 & 3 & $2,426.7$ & 431.1 \\
\hline
\end{tabular}

a No age-0 saugeyes were collected in Pleasant Hill Reservoir during July 2003; thus the mass from age-0 saugeyes in July 2002 was used.

Table 4. - Mean gizzard shads size density, and biomass estimated with mobile acoustic surveys in three Ohio reservoirs during July 2002-July 2003 ( $N=$ number of 250 -m transects randomly drawn for analysis).

\begin{tabular}{|c|c|c|c|c|c|c|c|c|c|c|}
\hline \multirow[b]{3}{*}{ Reservoir } & \multirow[b]{3}{*}{ Survey date } & \multirow[b]{3}{*}{$N$} & \multirow{3}{*}{$\begin{array}{c}\text { Mean } \\
\text { length } \\
(\mathrm{mm})\end{array}$} & \multirow{3}{*}{$\begin{array}{c}\text { Mean } \\
\text { mass }(\mathrm{g})\end{array}$} & \multicolumn{6}{|c|}{ Combined surveys } \\
\hline & & & & & \multicolumn{2}{|c|}{ Density (fish/ha) } & \multicolumn{2}{|c|}{ Biomass (kg/ha) } & \multicolumn{2}{|c|}{ Total biomass $(\mathrm{kg})$} \\
\hline & & & & & Mean & $\mathrm{SE}$ & Mean & $\mathrm{SE}$ & Mean & $\mathrm{SE}$ \\
\hline \multirow[t]{5}{*}{ Burr Oak } & 15 Jul 2002 & 20 & 97 & 9.15 & 4,118 & 535 & 37.7 & 4.9 & 9,455 & 1,227 \\
\hline & 6 Nov 2002 & 20 & 93 & 7.99 & 8,806 & 1,379 & 70.4 & 11.0 & 17,660 & 2,766 \\
\hline & 31 Mar 2003 & 20 & 82 & 5.61 & 4,246 & 1,278 & 23.8 & 7.2 & 5,979 & 1,800 \\
\hline & 14 May 2003 & 20 & 39 & 0.74 & 13,521 & 1,900 & 10.0 & 1.4 & 2,497 & 351 \\
\hline & 10 Jul 2003 & 20 & 109 & 12.66 & 3,412 & 480 & 43.2 & 6.1 & 10,842 & 1,525 \\
\hline \multirow[t]{5}{*}{ Piedmont } & 18 Jul 2002 & 36 & 48 & 1.30 & 18,638 & 1,532 & 24.2 & 2.0 & 22,025 & 1,818 \\
\hline & 3 Nov 2002 & 36 & 91 & 7.60 & 6,405 & 984 & 48.7 & 7.5 & 44,241 & 6,799 \\
\hline & 4 Apr 2003 & 36 & 103 & 10.65 & 259 & 55 & 2.8 & 0.1 & 2,509 & 53 \\
\hline & 16 May 2003 & 36 & 47 & 1.22 & 4,148 & 1,256 & 5.1 & 1.5 & 4,609 & 1,391 \\
\hline & 9 Jul 2003 & 36 & 61 & 2.48 & 26,567 & 3,115 & 65.9 & 7.7 & 59,891 & 7,022 \\
\hline \multirow[t]{5}{*}{ Pleasant Hill } & 16 Jul 2002 & 20 & 53 & 1.73 & 55,977 & 7,976 & 96.6 & 13.8 & 30,152 & 4,296 \\
\hline & 4 Nov 2002 & 20 & 139 & 24.99 & 11,816 & 2,328 & 295.3 & 58.2 & 92,143 & 18,152 \\
\hline & 3 Apr 2003 & 20 & 122 & 17.03 & 2,565 & 1,053 & 43.7 & 17.9 & 13,629 & 5,595 \\
\hline & 13 May 2003 & 20 & 158 & 35.17 & 2,634 & 976 & 92.6 & 34.3 & 28,901 & 10,714 \\
\hline & 14 Jul 2003 & 20 & 45 & 1.08 & 53,784 & 9,054 & 58.2 & 9.8 & 18,143 & 3,054 \\
\hline
\end{tabular}

Across reservoirs, over 99\% of the gizzard shad consumed by saugeyes (91-682 mm TL) were $150 \mathrm{~mm}$ TL or smaller. Saugeyes consistently consumed gizzard shad prey below the optimal prey length (33\% of TL) suggested by Nielsen (1980), but gizzard shad prey lengths were similar to lengths consumed by walleyes in Lake Erie (Knight et al. 1984; Figure 2). The length range of gizzard shad consumed increased with saugeye TL (Figure 2), but larger saugeyes $(>300 \mathrm{~mm} \mathrm{TL})$ continued to eat small gizzard shad $(<100 \mathrm{~mm} \mathrm{TL})$ throughout the year.

Across reservoirs, gizzard shad biomass consumed by saugeyes did not change as gizzard 
shad density increased. Within reservoirs, gizzard shad biomass consumed by saugeyes only varied by $0.00-0.010 \mathrm{~g} / \mathrm{g}$ (without any trend) as gizzard shad biomass increased (regression analysis: $N=15, P=0.78, r^{2}=0.006$ ).

\section{Saugeye Abundance Estimates}

Using stocking density (fish/ha) and CPUE (fish/h) of age-0 saugeyes during November 2002, we calculated survival to fall (oversummer survival) for age-0 saugeyes in 2002 (Figure 3). During 2002 and 2003, oversummer survival of age- 0 saugeyes was less than $8 \%$ in all reservoirs. Oversummer age-0 saugeye survival in 2002 was highest in Pleasant Hill Reservoir (7.4\%), lower in Piedmont Reservoir (3.0\%), and lowest in Burr Oak Reservoir (1.9\%) (Figure 3). Oversummer age- 0 saugeye survival in 2003 in descending order was as follows: $6.2 \%$ in Piedmont Reservoir, 2.5\% in Burr Oak Reservoir, and 2.2\% in Pleasant Hill Reservoir.

We created catch curves based on electrofishing CPUE during November 2002. From these curves, we determined that total annual survival for saugeyes was highest in Burr Oak Reservoir, lower in Piedmont Reservoir, and lowest in Pleasant Hill Reservoir (Figure 3). High summer survival did not necessarily correlate with high total annual survival. In 2002, oversummer survival of age- 0 saugeyes was lowest in Burr Oak Reservoir and highest in Pleasant Hill Reservoir, whereas total annual adult (age $\geq 1$ ) survival was highest in Burr Oak Reservoir and lowest in Pleasant Hill Reservoir.

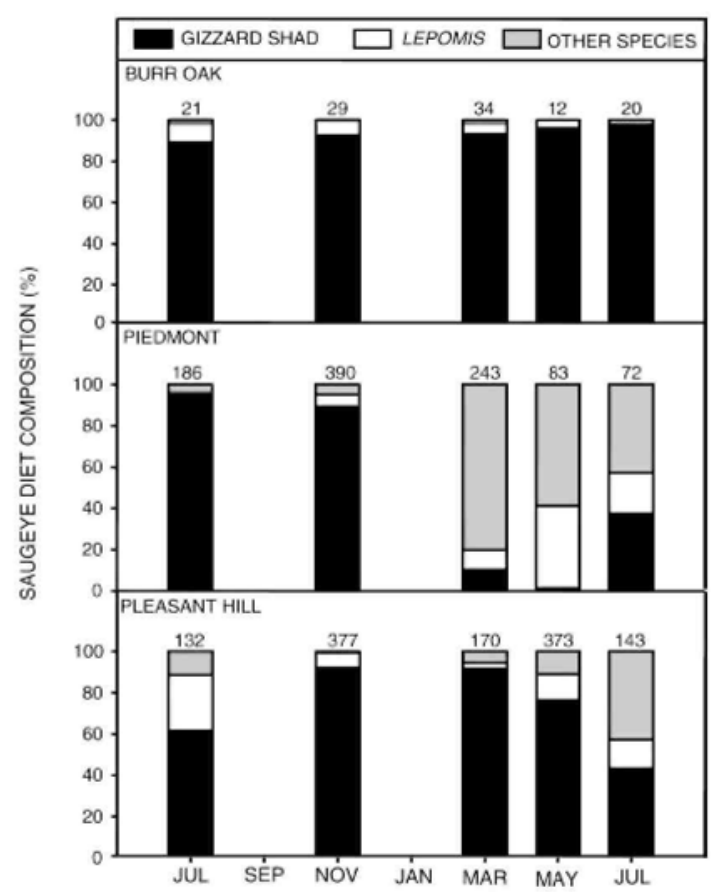

Figure 1. - Diet composition of all age-classes of saugeyes collected from three Ohio reservoirs with electrofishing and gill nets, July 2002-July 2003. The number above each bar indicates the number of saugeyes represented. 


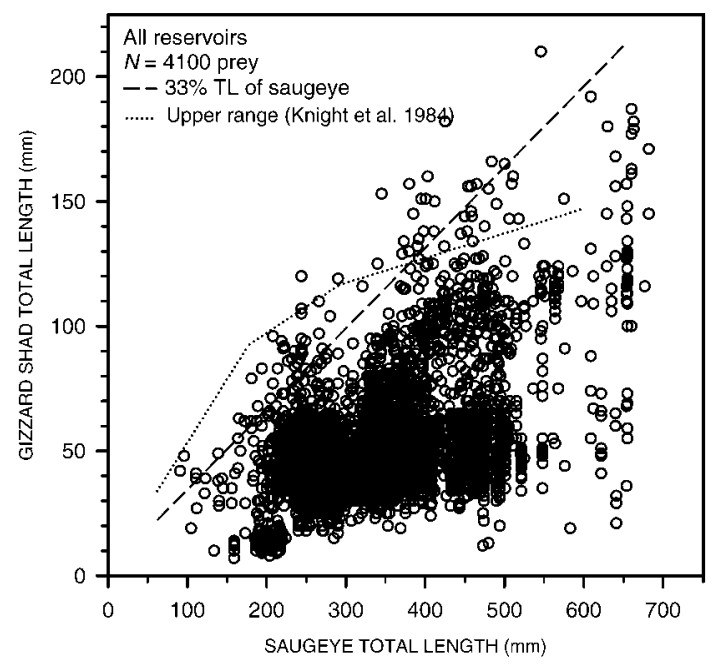

Figure 2. - Total lengths (TL) of gizzard shad prey plotted against TLs of saugeye predators in three reservoirs in Ohio during July 2002-July 2003. The dashed line indicates the "optimal" prey length for walleyes estimated by Nielsen (1980), and the dotted line indicates the upper range of prey length for walleyes estimated by Knight et al. (1984). 

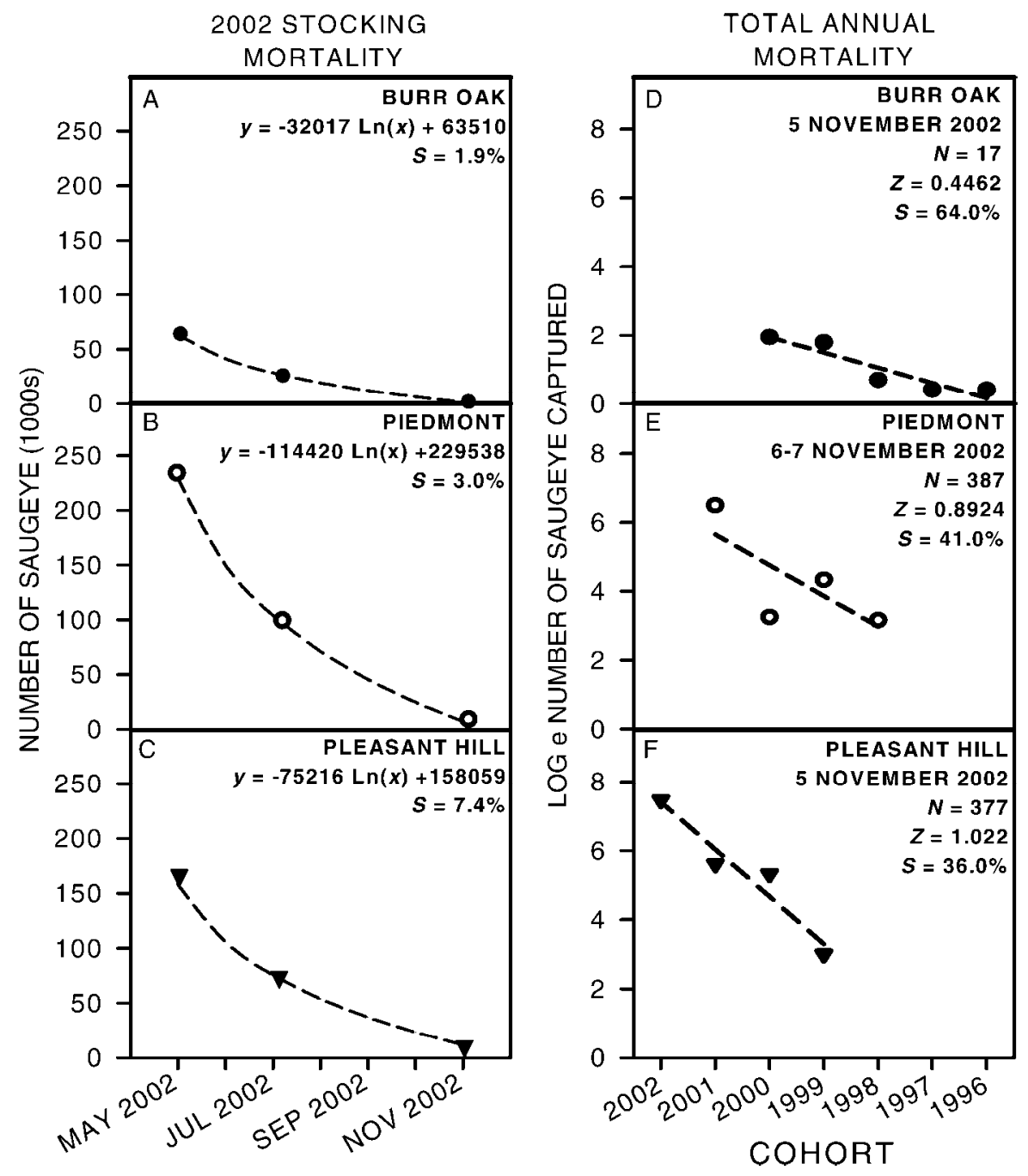

Figure 3. - Population estimators and catch curves for (A-C) age-0 and (D-F) adult saugeyes in three Ohio reservoirs during 2002. The data points on panels (A-C) are (from left to right) the numbers at stocking from hatchery records, July population estimates (interpolated between the time of stocking and the fall population estimate based on a natural $\log$ fit to the number stocked and estimated population size), and fall CPUE electrofishing collections based on ages determined from otoliths. Abbreviations are as follows: $S=$ calculated survival rate; $N=$ sample size; and $Z$ $=$ calculated instantaneous mortality rate. 
Table 5. - Seasonal proportion of maximum consumption $(P)$ and the mean seasonal $P$-values across saugeye cohorts from 2003 (age 0) through $\leq 1999$ (age $\geq 3$ ) from three Ohio reservoirs sampled during July 2002-July 2003. The mean value for each simulation period is shown in parentheses.

\begin{tabular}{cccccc}
\hline & & \multicolumn{5}{c}{ Simulated dates } \\
\cline { 3 - 6 } $\begin{array}{c}\text { Reservoir } \\
\text { and cohort }\end{array}$ & $\begin{array}{c}\text { Age in 2002 } \\
\text { (years) }\end{array}$ & $\begin{array}{c}7 \text { Jul- } \\
\text { 17 Nov 2002 }\end{array}$ & $\begin{array}{c}\text { 18 Nov 2002- } \\
8 \text { Mar 2003 }\end{array}$ & $\begin{array}{c}9 \text { Mar- } \\
18 \text { May 2003 }\end{array}$ & $\begin{array}{c}19 \text { May- } \\
\text { 20 Jul 2003 }\end{array}$ \\
\hline Burr Oak & & & & & \\
2003 & $<1^{\mathrm{a}}$ & & & & 0.6727 \\
2002 & $<1$ & 0.6331 & 0.4973 & 0.2122 & 0.3854 \\
2001 & 1 & 0.5279 & 0.2407 & 0.5985 & 0.4505 \\
2000 & 2 & 0.4388 & 0.4821 & 0.2864 & 0.4430 \\
$\leq 1999$ & $\geq 3$ & 0.4496 & 0.3469 & 0.1058 & 0.1267 \\
All & & $(0.5124)$ & $(0.3918)$ & $(0.3007)$ & $(0.4157)$ \\
Piedmont & & & & & \\
2003 & $<1^{\mathrm{a}}$ & & & & 0.6920 \\
2002 & $<1$ & 0.6793 & 0.5282 & 0.1265 & 0.4945 \\
2001 & 1 & 0.5261 & 0.3165 & 0.0843 & 0.3244 \\
2000 & 2 & 0.4072 & 0.3595 & 0.0016 & 0.6336 \\
$\leq 1999$ & $\geq 3$ & 0.4622 & 0.2411 & 0.1346 & 0.2977 \\
All & & $(0.5187)$ & $(0.3613)$ & $(0.0867)$ & $(0.4884)$ \\
Pleasant Hill & & & & & \\
2003 & $<1^{\mathrm{a}}$ & & & & 0.7340 \\
2002 & $<1$ & 0.6538 & 0.5583 & 0.0024 & 0.2502 \\
2001 & 1 & 0.5536 & 0.4016 & 0.2311 & 0.4639 \\
2000 & 2 & 0.4849 & 0.4495 & 0.1429 & 0.5037 \\
$\leq 1999$ & $\geq 3$ & 0.3139 & 0.4332 & 0.0351 & 0.4139 \\
All & & $(0.5016)$ & $(0.4607)$ & $(0.1029)$ & $(0.4731)$ \\
\hline
\end{tabular}

${ }^{a}$ These fish were age 0 in 2003 and could only be sampled during the July 2003 sample. Age in 2002 (second column) was always consistent with all other data presentations.

\section{Consumptive Demand}

Seasonal $P$-values, which indicate the consumed proportion of $C_{\max }$, for all saugeye cohorts through each season were highest (always $>0.6$ ) during July-November 2002 as a result of rapid growth (Table 5). Through the year, mean $P$-values across reservoirs were lowest during March-May 2003 (Table 5). Across seasons and within reservoirs, adult saugeye cohorts consumed similar proportions of $C_{\max }$. Growth patterns across cohorts led to similar $P$-values, given that saugeyes were subjected to similar temperature regimes across lakes. Variation in $P$ values between cohorts was therefore derived from compositional changes in saugeye diets.

Across reservoirs, gizzard shad contributed the greatest proportion to saugeye cumulative consumption through the year; only a few exceptions were noted: in Burr Oak Reservoir during July 2002 Piedmont Reservoir during March and May 2003 and Pleasant Hill Reservoir during May and July 2003, non-gizzard shad prey were most important (Figure 4). Total cumulative consumption of all prey varied across seasons but was highest across reservoirs during July 2002 (Figure 4). During July 2002, saugeyes consumed the greatest proportion of gizzard shad total standing stock in Piedmont Reservoir ( $>70 \%)$, followed by Pleasant Hill $(42 \%)$ and Burr Oak (25\%) reservoirs. 


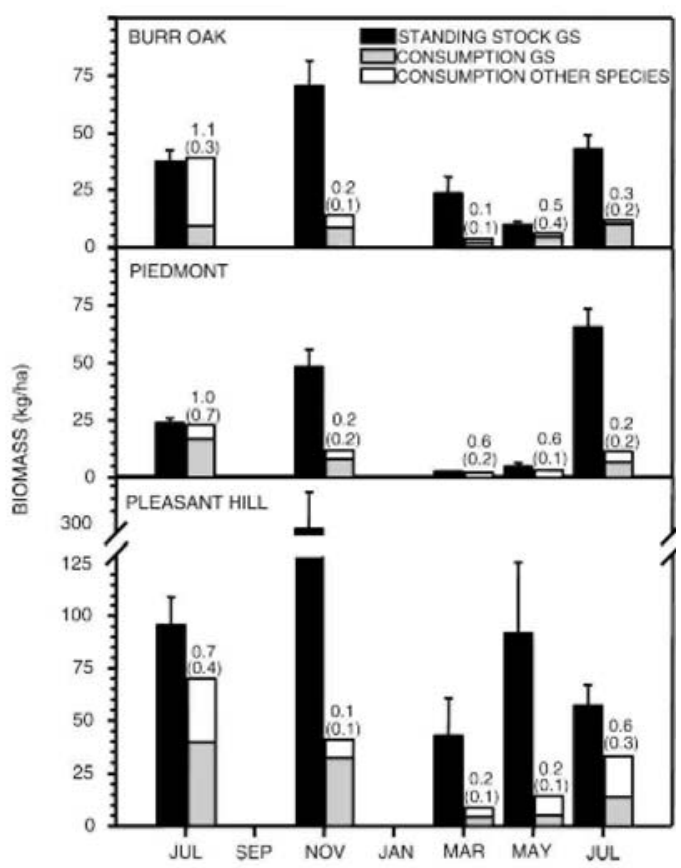

Figure 4. - Acoustic survey estimates of gizzard shad (GS) standing stock (biomass; $\mathrm{kg} / \mathrm{ha}$ ) and cumulative prey consumption $(\mathrm{kg} / \mathrm{ha}$ ) by saugeyes in three Ohio reservoirs, July 2002-July 2003. The top number above each set of bars is the ratio of total prey consumed to GS standing stock, and the bottom number (in parentheses) is the ratio of GS consumed to GS standing stock. A value of 1.0 indicates that saugeye consumption is equal to GS standing stock.

Cumulative saugeye consumptive demand during July 2002 approached the estimated standing stock of gizzard shad in Piedmont and Pleasant Hill reservoirs and marginally exceeded the estimated standing stock of gizzard shad in Burr Oak Reservoir. In addition, gizzard shad were the dominant prey of saugeyes in Piedmont and Pleasant Hill reservoirs, and saugeyes nearly consumed the entire estimated standing stock of gizzard shad. Because non-gizzard shad species were the most important prey consumed by saugeyes in Burr Oak Reservoir during July 2002, the margin between gizzard shad standing stock and consumption of gizzard shad was large. Consumptive demand of the saugeye population in Burr Oak Reservoir was sufficient to overexploit the gizzard shad population, but only if the diet had been composed solely of gizzard shad.

Across all reservoirs during November 2002, gizzard shad biomass increased while saugeye consumption of gizzard shad declined, increasing the margin between gizzard shad standing stock and saugeye consumption of gizzard shad (Figure 4). Cumulative consumption of gizzard shad was less than $17 \%$ of gizzard shad standing stock across all reservoirs during November 2002.

Cumulative consumption by saugeyes across reservoirs differed seasonally only during July 2002 and March 2003 (one-way ANOVA: $N=15, P=0.047$; subsequent Tukey's HSD: $\alpha=$ 0.05 ; Figure 4). Consumption by saugeyes was similar among all other seasons (one-way 
ANOVA: $N=12, P>0.11$ ). Total prey consumption by saugeyes was again close to estimates of gizzard shad standing stock in Piedmont Reservoir during March and May 2003 and exceeded half of the standing stock in Pleasant Hill Reservoir during July 2003.

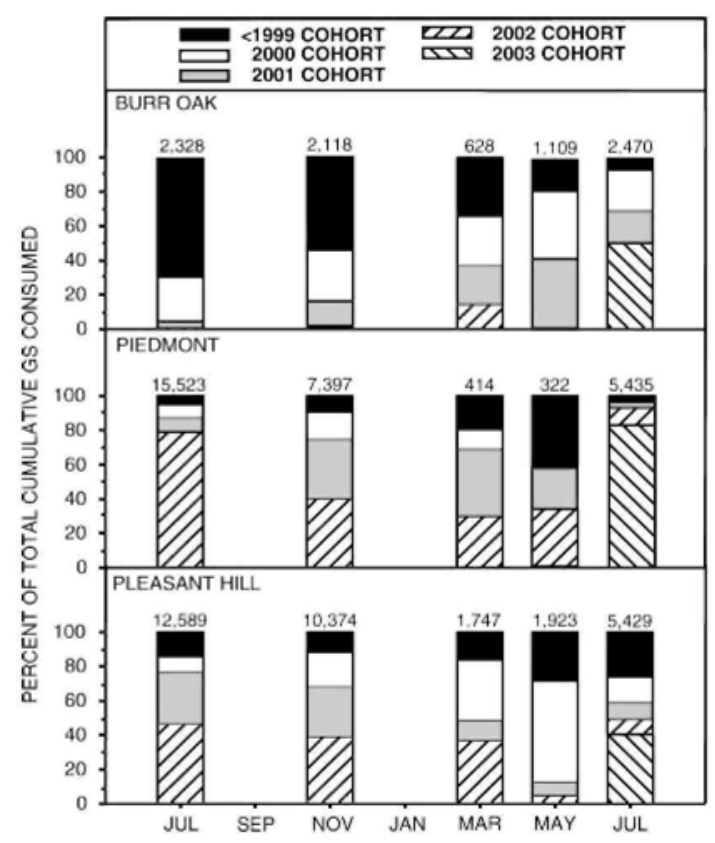

Figure 5. - Cumulative consumption of gizzard shad (GS) by each saugeye cohort in three Ohio reservoirs during July 2002-July 2003. The number above each bar is the total GS mass consumed (kg) by saugeyes during each season.

Unexpectedly, age-0 saugeyes in Piedmont and Pleasant Hill reservoirs consumed the greatest proportion of gizzard shad biomass among all saugeye cohorts during July and November 2002 and July 2003 (Figure 5). A high abundance of age-0 saugeyes after stocking strongly contributed to cumulative consumption by the saugeye population. In Burr Oak Reservoir, however, consumption by age- 0 saugeyes during July and November 2002 was negligible owing to poor oversummer survival $(<2 \%)$; in this system, age-3 and older saugeyes consumed the most gizzard shad.

For the LSDG, ISDG, and HSDG hypothetical scenarios, saugeye consumptive demand was generally highest during July and November 2002 and July 2003. During March and May 2003, across scenarios, saugeyes consumed few gizzard shad (Figure 6). Mean consumptive demand varied similarly across seasons between the LSDG (6.9 kg/ ha) and ISDG $(39.2 \mathrm{~kg} / \mathrm{ha})$ simulations, and both values were lower than the consumptive demand in the HSDG (166.3 $\mathrm{kg} / \mathrm{ha}$ ) simulation (one-way ANOVA: $N=15, P<0.001$ ).

Obviously, as we increased age- 0 and adult saugeye survival and seasonal growth rates and the proportion of gizzard shad in saugeye diets, saugeye consumptive demand increased (Figure 6). Across reservoirs, gizzard shad biomass generally met or exceeded saugeye consumptive demand modeled in both the LSDG and ISDG simulations across seasons. In the 
HSDG simulations for Burr Oak and Piedmont reservoirs, saugeye consumptive demand always exceeded gizzard shad biomass by 3-42 times (median $=6$ ). In Pleasant Hill Reservoir under HSDG conditions, saugeye consumptive demand generally exceeded gizzard shad standing stock except during November 2002. During all other seasons, saugeye consumptive demand exceeded gizzard shad biomass by two to six times (median $=2$ ).

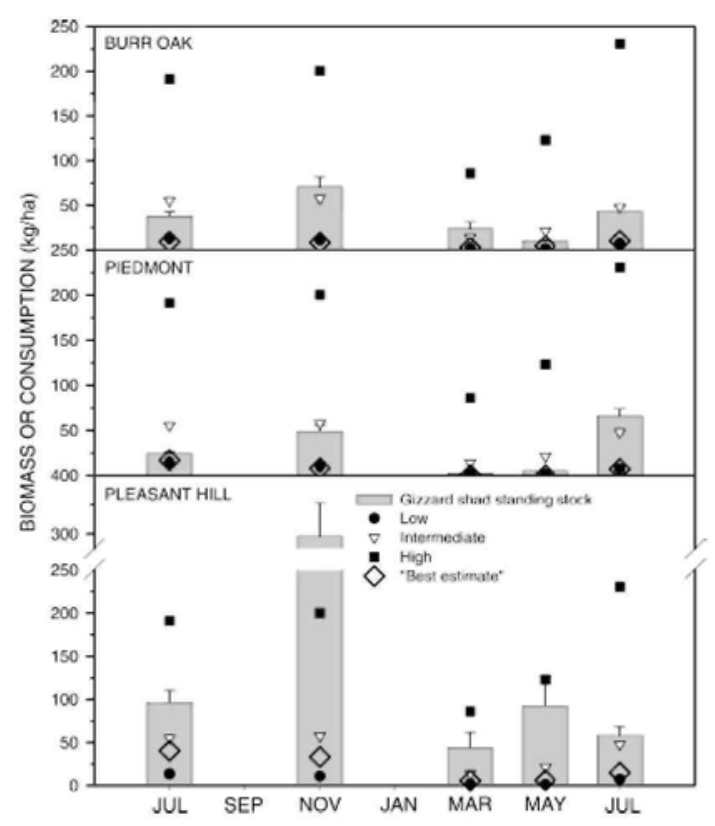

Figure 6. - Biomass of gizzard shad in three Ohio reservoirs during July 2002-July 2003 (vertical bars) and seasonal cumulative consumption of gizzard shad $(\mathrm{kg} / \mathrm{ha})$ by saugeyes shown for the best-estimate and three simulated scenarios (low, intermediate, and high oversummer age-0 saugeye survival, annual adult saugeye survival [S], proportion of gizzard shad in saugeye diets [D], and seasonal saugeye growth [G]; LSDG, ISDG, and HSDG).

\section{Discussion}

Combining acoustic survey estimates of gizzard shad abundance and biomass with bioenergetics model scenarios of saugeye consumption demonstrated that gizzard shad biomass generally supported stocked saugeye consumptive demand in three Ohio reservoirs during July 2002-July 2003. Spring and summer were critical periods when either prey supply was very low (spring) or predator demand was great relative to prey availability (summer). During spring, gizzard shad biomass was low and saugeyes consumed primarily alternative prey, including sunfishes, yellow perch, log-perch, and minnows. Although saugeyes consumed similar proportions of gizzard shad and alternative prey during summer 2002, cumulative consumptive demand by the entire saugeye population was high and approached the gizzard shad standing stock. During fall and winter, gizzard shad supply was adequate to support saugeye demand. Across reservoirs and seasons, saugeyes rarely consumed important resident sport fishes such as crappies or largemouth bass. Even though predatory demand and prey supply varied seasonally, gizzard shad biomass generally met consumptive requirements of stocked saugeyes with our best-estimate, LSDG, and ISDG bioenergetics scenarios. Saugeye consumptive demand in the HSDG scenario often exceeded gizzard shad biomass. 


\section{Characterizing Gizzard Shad Density, Size, and Biomass}

Acoustic surveys have been widely used to quantify the density, biomass, and distribution of fish populations in a variety of aquatic systems (Brandt et al. 1991; MacLennan and Simmonds 1992; Degan and Wilson 1995). Relative to traditional gear (e.g., quadrat rotenone: Johnson et al. 1988b, Schaus et al. 1997; gill nets: Gido and Matthews 2000; electrofishing: Irwin et al. 2003a), acoustic surveys allow researchers to sample reservoirwide fish populations with less time and effort. Gear limitations in shallow water could potentially underestimate gizzard shad population size, while the complexities of estimating fish length distributions from target strength could potentially cause overestimation of prey availability (MacLennan and Simmonds 1992; Thomas et al. 2002). However, multiple limnetic electrofishing surveys (depths $>1.5 \mathrm{~m}$ ) during July-October 1998-2000 in Burr Oak and Pleasant Hill reservoirs revealed that gizzard shad constituted a consistently high proportion of overall catch rates $(93.5 \%$ and $94.1 \%$, respectively) (M.J. Vanni, Miami University, Oxford, Ohio, unpublished data). Likewise, gill-net data collected during fall 2004 indicated that gizzard shad were the dominant species in Burr Oak and Pleasant Hill reservoirs, accounting for overall catch rates of $83.9 \%(N=459$ fish) and $94.2 \%(N=636$ fish), respectively (Ohio Department of Natural Resources, Division of Wildlife, unpublished data). Given the high proportion of gizzard shad sampled with traditional gear, we feel that our acoustic-derived estimates of gizzard shad abundance are probably conservative. Refinement of littoral sampling techniques and development of a species-specific target strength-length relation for gizzard shad, in addition to concurrent sampling with alternate gear, would aid in resolving these concerns.

\section{Saugeye Prey}

As with other studies, we found that gizzard shad were the primary prey for saugeyes across reservoirs (Humphreys et al. 1987; Johnson et al. 1988a; Leeds 1989; Holton and Gilliland 1992; Boxrucker 2002). However, during spring and summer 2003, saugeyes in Piedmont and Pleasant Hill reservoirs shifted from gizzard shad to alternative fish prey, such as sunfishes, yellow perch, logperch, and minnows. Across reservoirs and seasons, saugeyes rarely consumed age-0 largemouth bass or crappies, even during seasons with low gizzard shad biomass.

Gizzard shad growth rates may regulate the "window of opportunity" for prey consumption and subsequent saugeye growth, as fast-growing gizzard shad will be available for a shorter time period than slow-growing gizzard shad (Bremigan 1997; Michaletz 1999). Therefore, increased gizzard shad biomass is not synonymous with increased prey availability, gizzard shad consumption, or growth. Given the important role of gizzard shad in saugeye diets across Ohio reservoirs, an understanding of the link between fish growth (gizzard shad and saugeyes alike) and gizzard shad predation vulnerability may help explain the range of saugeye growth observed in Burr Oak, Piedmont, and Pleasant Hill reservoirs.

\section{Saugeye Survival}

Similar to observations by Donovan et al. (1997), oversummer survival of age-0 saugeyes varied during 2002 and 2003 in Burr Oak, Piedmont, and Pleasant Hill reservoirs and probably resulted from gizzard shad availability at stocking (Donovan et al. 1997). Population-level saugeye consumptive demand for gizzard shad was driven by age- 0 saugeyes in all reservoirs. When oversummer survival of age-0 saugeyes was greater than $2 \%$, these cohorts accounted for nearly half of the total gizzard shad consumed during early summer. Through time, or when age- 
0 oversummer survival was less than $2 \%$, the contribution of age- 0 saugeye cohorts was less important. Annual survival of adult saugeyes was greatest in Burr Oak Reservoir, lower in Piedmont Reservoir, and lowest in Pleasant Hill Reservoir. Although Burr Oak Reservoir's adults survived better than adults in Piedmont and Pleasant Hill reservoirs, the over-summer survival of stocked saugeyes $(<2.5 \%$ in 2002 and 2003) produced few recruits and therefore few adult saugeyes. By reducing harvest through angling restrictions, saugeye consumptive demand for gizzard shad within reservoirs could be increased.

\section{Bioenergetics Model Considerations}

During July-November 2002, saugeyes from all reservoirs had the greatest seasonal proportion of $C_{\max }(>0.6)$ across cohorts, driven largely by measured growth rates. This seasonal consumption matched consumption by saugeyes in Kokosing Lake, Ohio, during JuneSeptember 1984 (Johnson et al. 1988b). By varying saugeye survival and growth within a range of documented field values, we determined the consumptive potential of stocked saugeyes. The LSDG, ISDG, and HSDG simulations provided a range of saugeye consumptive demand and a context for our best-estimate, reservoir-specific simulations. Our best-estimate simulations across reservoirs were most similar to LSDG and ISDG simulations, suggesting that the potential consumptive demand by saugeye populations in our study reservoirs is regulated most strongly by a combination of survival (age-0 and adult fish) and seasonal growth. Quantifying saugeyespecific vital parameters on a statewide basis, as initiated by the Ohio Division of Wildlife in 2003, will provide crucial data regarding this issue. Whereas density-dependent mechanisms may preclude HSDG scenarios, these density-dependent effects may be small. If so, then saugeyes may potentially overexploit gizzard shad. In our best-estimate simulations, saugeyes shifted their diets to include non-gizzard shad fishes (primarily sunfishes, yellow perch, logperch, and minnows, but rarely crappies or largemouth bass) during times of low gizzard shad abundance. An HSDG situation may cause a greater shift in diets to include non-gizzard shad prey, potentially sport fishes. Because consumptive demand in our study reservoirs was most similar to LSDG and ISDG simulations, the potential severity of this diet shift remains unknown.

The yellow perch bioenergetics model (Hewett and Johnson 1992), upon which the walleye bioenergetics model (Kitchell et al. 1977) is based, has undergone numerous evaluations (Hewett and Johnson 1992; Karås and Thoresson 1992; Hanson et al. 1997; Schaeffer et al. 1999; Bajer et al. 2003). The results from each iteration highlight the importance of a multifaceted approach to bioenergetics model evaluations. Similar to these and other model evaluations for largemouth bass (Rice and Cochran 1984), juvenile walleyes (Madon and Culver 1993), juvenile hybrid sunfishes (Whitledge et al. 1998), smallmouth bass $M$. dolomieu (Whitledge et al. 2003), and sea lampreys Petromyzon marinus (Cochran et al. 1999), validation of the walleye model for use with saugeyes is a necessary next step in its use.

\section{Gizzard Shad Consumption by Piscivores}

Saugeyes are not the sole predators of gizzard shad in Ohio reservoirs. Other piscivores, such as largemouth bass (Carline et al. 1984; Johnson et al. 1988b), crappies, white bass, catfishes, and muskellunge Esox masquinongy probably consume gizzard shad, adding to the predatory demand on gizzard shad populations. In Kokosing Lake, the combined consumptive demand during summer by age-0 stocked predators (percids and esocids) and resident largemouth bass was $14.5 \mathrm{~kg} / \mathrm{ha}$, only about $20 \%$ of the total standing stock of age- 0 gizzard shad, allowing a surplus in gizzard shad biomass to persist (Johnson et al. 1988b). However, 
using bioenergetics models applied to the dense $(33.4 \mathrm{~kg} / \mathrm{ha})$ largemouth bass population in Knox Lake, Ohio, Carline et al. (1984) found that annual consumptive demand by largemouth bass $(127 \mathrm{~kg} / \mathrm{ha})$ could approach theoretical gizzard shad production only during years of small age-0 gizzard shad classes (118 versus $160-202 \mathrm{~kg} / \mathrm{ha}$ ). Seasonal gizzard shad biomass values in our reservoirs $($ mean $=2.8-295.3 \mathrm{~kg} / \mathrm{ha}$, median $=43.7 \mathrm{~kg} / \mathrm{ha}$ ) were generally lower than those assumed by Carline et al. (1984) for Knox Lake (103 kg/ ha). Given lower gizzard shad biomass, we expect the predatory pressure on this resource to be amplified. Comparisons between annual consumptive demand and prey biomass (Carline et al. 1984) are not entirely realistic and may in fact disguise seasonal bottlenecks between prey availability and consumptive demand. Our data, which was collected on a quarterly basis, probably provided better seasonal resolution. Consideration of both seasonal influences and predators other than saugeyes provides a more comprehensive understanding of reservoirwide food web dynamics.

\section{Management Implications}

Matching predator consumptive demand to the prey supply should influence stocking success and resident food webs. Therefore, when stocking predators in lakes and reservoirs, managers should consider consumptive demand, prey resources, and the potential variation in survival and growth of stocked fishes.

Our general saugeye bioenergetics model simulations (LSDG, ISDG, and HSDG) provide a means to quantify how saugeye biotic parameters influence their consumptive demand potential. A key bottleneck for meeting peak consumptive demand appears to be the availability of gizzard shad during summer. Fewer saugeyes should be stocked in reservoirs with chronically low gizzard shad densities, whereas reservoirs with historically high gizzard shad densities could receive additional saugeyes or other piscivores. Managers could amplify saugeye predatory demand through increased rates of stocking, conceivably leading to higher numbers of a fastgrowing age- 0 saugeye cohort characterized by high consumption. Higher adult survival, which also translates to increased predatory demand, can be achieved though protective length limits or reduced creel limits if natural mortality and catch-and-release mortality are high. Experimenting with such an approach may allow saugeyes to further exploit available prey if stocking increases are prevented by limits in hatchery production or if managers seek to create fisheries where anglers may catch fewer, but larger, fish. Current rates of saugeye stocking in Ohio (typically $247 \mathrm{fish} / \mathrm{ha}$ ) do not appear to generate consumptive demand that exceeds gizzard shad supply if our study reservoirs are reasonably representative of the 57 Ohio reservoirs stocked with saugeyes. These rates do not appear to compromise saugeye growth or survival. Thus, reservoir managers in Ohio may have the opportunity to further capitalize on prey resources by reallocating hatchery production to increase predator stocking in reservoirs with consistently abundant gizzard shad.

\section{Acknowledgments}

We thank M. Cousins, S. Fedor, K. Flaute, A. Jacobs, and T. Prior for their assistance in the field and laboratory. A. Kulesza was instrumental in providing leadership in the field and laboratory, and in data analysis. Thanks are extended to Ohio Wildlife Districts 2 and 4 and the Inland Fish Research Unit for assistance in field sampling. D. Degan, Aquacoustics, Inc., provided analysis of acoustics data and insights into acoustic survey results. Funding for this research was provided by the Ohio Department of Natural Resources, Division of Wildlife; Federal Aid in Sport Fish Restoration Project F-69-P, Fish Management in Ohio; and the 


\section{Department of Evolution, Ecology, and Organismal Biology at The Ohio State University.}

\section{References}

Aprahamian, M. W., K. M. Smith, P. McGrinnity, S. McKelvey, and J. Taylor. 2003. Restocking of salmonids: opportunities and limitations. Fisheries Research 62:221-227.

Bajer, P. G., G. W. Whitledge, R. S. Hayward, and R. D. Zweifel. 2003. Laboratory evaluation of two bioenergetics models applied to yellow perch: identification of a major source of systematic error. Journal of Fish Biology 62:436-454.

Boxrucker, J. 2002. Improved growth of a white crappie population following stocking of saugeyes (sauger $\times$ walleye): a top-down, density-dependant growth response. North American Journal of Fisheries Management 22:1425-1437.

Brandt, S. B., D. M. Mason, E. V. Patrick, R. L. Argyle, L. Wells, and P. A. Unger. 1991. Acoustic measures of the abundance and size of pelagic planktivores in Lake Michigan. Canadian Journal of Fisheries and Aquatic Sciences 48:894-908.

Bremigan, M. T. 1997. Variable recruitment of gizzard shad, a strong interactor in reservoirs: exploring causal mechanisms and implications for food webs. Doctoral dissertation. Ohio State University, Columbus.

Bremigan, M. T. and R. A. Stein. 2001. Variable gizzard shad recruitment with reservoir productivity: causes and implications for classifying systems. Ecological Applications 11:1425-1437.

Bryan, S. D., C. A. Soupir, W. G Duffy, and C. E. Freiburger. 1996. Caloric densities of three predatory fishes and their prey in Lake Oahe, South Dakota. Journal of Freshwater Ecology 11:153-161.

Bryant, H. E., and D. I. Morais. 1970. Identification of ingested gizzard shad and threadfin shad by gizzard dimensions. Technical Papers of the Bureau of Sport Fisheries and Wildlife 51:3-5.

Burczynski, J. J., P. H. Michaletz, and G M. Marrone. 1987. Hydroacoustic assessment of the abundance and distribution of rainbow smelt in Lake Oahe. North American Journal of Fisheries Management 7:106-116.

Carlander, K. D. 1958. Disturbance of the predator-prey balance as a management technique. Transactions of the American Fisheries Society 87:34-38.

Carline, R. F., B. L. Johnson, and T. J. Hall. 1984. Estimation and interpretation of proportional stock density for fish populations in Ohio impoundments. North American Journal of Fisheries Management 4:139-154.

Cochran, P. A., W D. Swink, and A. P. Kinziger. 1999. Testing and extension of a sea lamprey feeding model. Transactions of the American Fisheries Society 128:403-413.

Cummins, K. W., and J. C. Wuycheck. 1971. Caloric equivalents for investigations In ecological energies. Mitteilungen Internationale Vereinigung für Theoretischeund Angewandte Limnologie 18:1-158.

Degan, D. J., and W Wilson. 1995. Comparison of four hydroacoustic frequencies for sampling pelagic fish populations in Lake Texoma. North American Journal of Fisheries Management 12:407-416.

Dettmers, J. M., R. A. Stein, and E. M. Lewis. 1998. Potential regulation of age-0 gizzard shad by hybrid striped bass in Ohio reservoirs. Transactions of the American Fisheries Society 127:84-94.

DeVries, D. R., and R. A. Stein. 1990. Manipulating shad to enhance sport fisheries in North America: an assessment. North American Journal of Fisheries Management 10:209-223.

Donovan, N. S., R. A. Stein, and M. M. White. 1997. Enhancing percid stocking success by understanding age-0 piscivore-prey interactions in reservoirs. Ecological Applications 7:1311-1329.

Eggold, B. T., and W. H. Horns. 2001. A comparison of two methods of rearing and stocking coho salmon in Wisconsin's waters of Lake Michigan. North American Journal of Fisheries Management 21:147-155.

Foote, K. G., and D. N. MacLennan. 1984. Comparison of copper and tungsten carbide spheres. Journal of the Acoustical Society of America 82:981-987.

Foster, J. R. 1977. Pulsed gastric lavage: an efficient method of removing the stomach contents of live fish. Progressive Fish-Culturist 39:166-169.

Gido, K. B., and W. J. Matthews. 2000. Dynamics of the offshore fish assemblage in a southwestern reservoir (Lake Texoma, Oklahoma-Texas). Copeia 2000:917-930.

Hanson, P. C., T. B. Johnson, D. E. Schindler, and J. F Kitchell. 1997. Fish bioenergetics 3.0. University of Wisconsin, Sea Grant Institute, Sea Grant Technical Report, WISCU-T-97-001, Madison.

Henderson, B. A., T. Trivedi, and N. Collins. 2000. Annual cycle of energy allocations to growth and reproduction of yellow perch. Journal of Fish Biology 57:122-133.

Hewett, S. W., and B. L. Johnson. 1992. Fish bioenergetics model 2: an upgrade of a generalized bioenergetics model of fish growth for microcomputers. University of Wisconsin, Sea Grant Institute, Technical Report 
WIS-SG-92- 250, Madison.

Holton, R. A., and E. R. Gilliland. 1992. Diet overlap between saugeye and largemouth bass in Thunderbird Reservoir, Oklahoma. Proceedings of the Annual Conference Southeastern Association of Fish and Wildlife Agencies 44(1990):98-104.

Humphreys, M., J. L. Wilson, and D. C. Peterson. 1987. Growth and food habits of young of year walleye $\times$ sauger hybrids in Cherokee Reservoir, Tennessee. Proceedings of the Annual Conference Southeastern Association of Fish and Wildlife Agencies 38(1984):413-420.

Irwin, B. J., D. R. DeVries, and G. W. Kim. 2003a. Responses to gizzard shad recovery following selective treatment in Walker County Lake, Alabama, 1996-1999. North American Journal of Fisheries Management 23:1225-1237.

Irwin, B. J., D. R. DeVries, and R. A. Wright. 2003b. Evaluating the potential for predatory control of gizzard shad by largemouth bass in small impoundments: a bioenergetics approach. Transactions of the American Fisheries Society 132:913-924.

Johnson, B. L., D. L. Smith, and R. F. Carline. 1988a. Habitat preferences, survival, growth, foods, and harvests of walleye and walleye $\times$ sauger hybrids. North American Journal of Fisheries Management 8:292-304.

Johnson, B. M., R. A. Stein, and R. F. Carline. 1988b. Using a quadrat rotenone technique and bioenergetics modeling to evaluate forage fish size and abundance for stocked piscivores. Transactions of the American Fisheries Society 117:127-141.

Karås, P., and G. Thoresson. 1992. An application of bioenergetics model to Eurasian perch (Perca fluviatilis L.). Journal of Fish Biology 41:217-230.

Kitchell, J. K., D. J. Stewart, and D. Weininger. 1977. Applications of a bioenergetics model to yellow perch (Perca flavescens) and walleye (Stizostedion vitreum). Journal of the Fisheries Research Board of Canada 34:1922-1935.

Knight, R. L., F J. Margraf, and R. F. Carline. 1984. Piscivory by walleyes and yellow perch in western Lake Erie. Transactions of the American Fisheries Society 113:677-693.

Knoll, L. B., M. J. Vanni, and W. H. Renwick. 2003. Phytoplankton primary production and photosynthetic parameters in reservoirs along a gradient of watershed land use. Limnology and Oceanography 48:608617.

Kramer, R. H., and L. L. Smith. 1960. First-year growth of largemouth bass. Transactions of the American Fisheries Society 89:222-233.

Leeds, L. G. 1989. Growth and food habits of saugeye (walleye $\times$ sauger hybrids) in Thunderbird Reservoir, Oklahoma. Proceedings of the Annual Conference Southeastern Association of Fish and Wildlife Agencies 42(1988):243-248.

Leeds, L. G. 1992. Distribution, movement, and habitat preference of saugeye in Thunderbird Reservoir, Oklahoma. Proceedings of the Annual Conference Southeastern Association of Fish and Wildlife Agencies 44(1990):27-35.

Lotrich, V. A. 1973. Growth, production, and community composition of fishes inhabiting a first-, second-, and third-order stream of eastern Kentucky. Ecological Monographs 43:377-397.

Love, R. H. 1971. Dorsal-aspect target strength of an individual fish. Journal of the Acoustical Society of America 49:816-823.

Lynch, W. E., D. L. Johnson, and S. A. Schell. 1982. Survival, growth, and food habits of walleye $\times$ sauger hybrids (saugeye) in ponds. North American Journal of Fisheries Management 2:381-387.

MacLennan, D. N., and E. J. Simmonds. 1992. Fisheries acoustics. Chapman and Hall, New York.

Madon, S. P., and D. A. Culver. 1993. Bioenergetics model for larval and juvenile walleyes: an in situ approach with experimental ponds. Transactions of the American Fisheries Society 122:797-813.

Masser, M. P., W. E. Grant, W. H. Neill, and E. H. Robinson. 1991. A simulation model representing effects on dietary energy/protein ratio and water temperature on growth of channel catfish (Ictalurus punctatus). Ecological Modelling 53:17-35.

Michaletz, P. H. 1999. Influence of reservoir productivity and juvenile density on first-year growth of gizzard shad. North American Journal of Fisheries Management 19:842-847.

Miranda, L. E., and R. J. Muncy. 1991. Bioenergetic values of shads and sunfishes as prey for largemouth bass. Proceedings of the Annual Conference Southeastern Association of Fish and Wildlife Agencies 43(1989):153-163.

Nielsen, L. A. 1980. Effect of walleye (Stizostedion vitreum vitreum) predation on juvenile mortality and recruitment of yellow perch (Perca flavescens) in Oneida Lake, New York. Canadian Journal of Fisheries and Aquatic Sciences 37:11-19. 
Noble, R. L. 1981. Management of forage fishes in impoundments of the southern United States. Transactions of the American Fisheries Society 110:738-750.

Pope, K. L., M. L. Brown, W. G. Duffy, and P. H. Michaletz. 2001. A caloric-based evaluation of diet indices for largemouth bass. Environmental Biology of Fishes 61:329-339.

Rice, J. A., J. E. Breck, S. M. Bartell, and J. F. Kitchell. 1983. Evaluating the constraints of temperature, activity, and consumption on growth of largemouth bass. Environmental Biology of Fishes 9:263-275.

Rice, J. A., and P. A. Cochran. 1984. Independent evaluation of a bioenergetics model for largemouth bass. Ecology 65:732-739.

Schaeffer, J. S., R. C. Haas, J. S. Diana, and J. E. Breck. 1999. Field test of two energetic models for yellow perch. Transactions of the American Fisheries Society 128:414-435.

Schaus, M. H., M. J. Vanni, T. E. Wissing, M. T. Bremigan, J. E. Garvey, and R. A. Stein. 1997. Nitrogen and phosphorus excretion by detritivorous gizzard shad in a reservoir ecosystem. Limnology and Oceanography 42:1386-1397.

Secor, D. H., J. M. Dean, and E. H. Laban. 1991. Manual for otolith removal and preparation for microstructural examination. University of South Carolina, Baruch Institute for Marine Biology and Coastal Research, Technical Report 91-1, Columbia.

Silk, R. J. 2001. Fate of stocked saugeye during their first year of life, with an emphasis on quantifying movement within and from Ohio reservoirs. Master's thesis. Ohio State University, Columbus.

Spoelstra, J. A. 2001. Movement of reservoir-stocked saugeye between tailwaters, streams, and rivers. Master's thesis. Ohio State University, Columbus.

Stahl, T. P., and R. A. Stein. 1994. Influence of larval gizzard shad (Dorosoma cepedianum) density on piscivory and growth of young-of-year saugeye (Stizostedion vitreum $\times$ S. canadense). Canadian Journal of Fisheries and Aquatic Sciences 51:1993-2002.

Stewart, D. J., J. F. Kitchell, and L. B. Crowder. 1981. Forage fishes and their salmonid predators in Lake Michigan. Transactions of the American Fisheries Society 110:751-763.

Thomas, G. L., J. Kirsch, and R. E. Thorne. 2002. Ex situ target strength measurements of Pacific herring and Pacific sand lance. North American Journal of Fisheries Management 22:1136-1145.

Wahl, D. H., and R. A. Stein. 1991. Field testing an esocid bioenergetics model. Transactions of the American Fisheries Society 120:230-246.

Whitledge, G. W., R. S. Hayward, D. B. Noltie, and N. Wang. 1998. Testing bioenergetics models under feeding regimes that elicit compensatory growth. Transactions of the American Fisheries Society 127:740-746.

Whitledge, G. W., R. S. Hayward, R. D. Zweifel, and C. F. Rabeni. 2003. Development and laboratory evaluation of a bioenergetics model for subadult and adult smallmouth bass. Transactions of the American Fisheries Society 132:316-325. 